\title{
Patterns of Refugee Planning: A Comparative Analysis of Current Refugee Planning Approaches
}

\author{
Alyssa M. Wissel \\ School of Planning, University of Cincinnati, Cincinnati, OH, USA \\ Email: mccleaam@mail.uc.edu
}

How to cite this paper: Wissel, A. M. (2017). Patterns of Refugee Planning: A Comparative Analysis of Current Refugee Planning Approaches. Advances in Applied Sociology, 7, 349-363.

https://doi.org/10.4236/aasoci.2017.711023

Received: September 4, 2017

Accepted: November 5, 2017

Published: November 8, 2017

Copyright $\odot 2017$ by author and Scientific Research Publishing Inc. This work is licensed under the Creative Commons Attribution International License (CC BY 4.0).

http://creativecommons.org/licenses/by/4.0/

\section{(c) (i) Open Access}

\begin{abstract}
In 2015, there were more than 21 million refugees globally; as conflicts continue and globalization expands, it is advantageous for planners to strategically manage population influxes of ill-equipped families. Refugee policy decisions have imperative effects on housing markets, economies, segregation, international relations, and refugees' resilience. Bound by the 1967 Protocol on the Status of Refugees, every member state is obligated to protect refugees. This paper analyzes the varying conditions of refugees in the top six countries with the highest number of refugees; through a matrix, this paper compares what attributes promote effective refugee plans and which do not. Every conflict scenario is unique, and there are attributes that a refugee plan cannot change (length of conflict, host country's economy, status of host country's government, cultural clashes between local population and refugees). However, this paper seeks to empower planners to use policy in ways they can mitigate current and future refugee situations. This analysis concludes that refugee policies work best for the host country and the refugees when refugees: 1) are able to live outside of camps and in cities; 2) can be employed; 3) are distributed to not overwhelm housing/infrastructure; and there are multiple funding sources.
\end{abstract}

\section{Keywords}

Refugee, Policy, Planning, Population, International Norms

\section{Introduction}

Environmental degradation, civil war, natural disaster, territorial disputes, drug wars; refugees' hopes of fleeing terrible living conditions have been complicated by modern borders and political debates of international responsibility. Accord- 
ing to the world's highest authority on refugees, United Nations High Commissioner on Refugees (UNHCR), in 2015 there were more than 21 million refugees globally (UNHCR, 2015). The story of refugees evolves over time with varying sources of conflict, number of refugees, budgets, sentiments of support, and success of refugee programming.

Regardless of these discrepancies, people fleeing their homes from a "well-founded fear of persecution for reasons of race, religion, nationality, political opinion or membership in a particular social group" will not cease globally anytime soon (UNHCR, 2015). Understanding the nuances of failed refugee planning is vital to improving approaches in the future. This research is principal to not only mitigating mass migrations but capitalizing upon them. Policy-makers and planners should not only design with these populations in mind, but view refugees as an opportunity, especially for aging populations or supply-heavy economies. For instance, the (western) German Economic Miracle of the 1950s (Eichengreen \& Ritschl, 2008). Germany recovered rather quickly as a result of the Marshall Plan, which stimulated capital along with returning prisoners of war and an influx of Polish and Russian refugees as a labor force (UNHCR, 2015).

As of spring 2017, more than half of all refugees are Somali, Afghan, or Syrian (UNHCR, 2017). The dominant host countries are the following: Jordan 664 thousand; Ethiopia 736 thousand; Iran 979 thousand; Lebanon 1.1million; Pakistan 1.6 million; and Turkey 2.5 million (UNHCR, 2017). These populations are disproportionately desperate women and children, who frequently sink into gridlocked checkpoint processes and camps for years, or even lifetimes. The agreed upon expectations in the 1951 Convention on Refugees declares that all member states of the United Nations (UN) must provide the right to liberty and security of person, freedom of movement, right to family life, access to employment, courts, and education. However, this is a non-binding convention, not a binding covenant, which results in states cherry-picking parts of the law to include and exclude (International Justice Center, 2017). These ambiguous "obligations" mean that states have unique methods of refugee planning policy with varying levels of success.

This analysis seeks to explore the methods of refugee planning implemented by the top hosting countries (Jordan, Ethiopia, Lebanon, Pakistan, Iran, and Turkey) by comparing their success with indicators. By measuring which methods harbor successful refugee planning, future efforts can be executed more effectively. Yet another question arises from this; for whom is a plan successful? One must consider who benefits from these policies. Perhaps it is successful for peace building after the conflict; the refugees themselves; or the host country's reputation. The most successful refugee policies structurally, economically, and socially integrate refugees with the local population; however, such plans are not popular to implement.

\section{Historical Refugee Policy Precedents}

As the severity of the Holocaust became public, the world was shocked and 
vowed that these human rights violations would never occur again. The UN was established, and the Universal Declaration of Human Rights was written in 1948. This was the first internationally recognized document to define the "right to seek asylum" (United Nations, 1948). The (Fourth) Geneva Conventions of 1950 included the protection of refugees during times of war. This binding convention means that a government cannot treat refugees as aliens or enemies while said government experiences war (Geneva Convention, 1950). The Convention and Protocol Relating to the Status of Refugees of 1951 was soon followed by the first UN document devoted specifically to refugees. This legislation boldly concluded that states must grant refugees rights that are equal to foreign nationals living in said state or equal to national citizens. The 1951 Convention is arguably the most fundamental document to define the roles and responsibilities that host countries inherit and to define the rights, which refugees bear (United Nations, 1951). The weakness of the 1951 Convention is that it only defines refugees from events preceding 1951 (essentially the events of World War II) and was regarded as a Eurocentric responsibility. Suddenly, there were refugees from non-European theatres, and these regulations did not apply. This loophole was amended by the 1967 Protocol Relating to the Status of Refugees, which nullified the limitations of the 1951 Convention's assumptions; ergo international refugee law finally applied to any person in any place at any time (United Nations, 1967). There are countless UN documents that resemble unfeasible dreams rather than tangible obligations. Apart from the Universal Declaration of Human Rights, these papers are considered globally authorized, international law and not heart-warming aspirations.

Historical precedents built the construction of refugee norms just as much as official UN documents. Succeeding World War II, the United Nations Relief and Rehabilitation Administration (UNRRA) sought to manage refugee resettlement and stimulate the economy back to into Europe. The UNRRA was organized by the Allied powers, but primarily by the United States. It was comprehensive and effective but ran out of funding after only four years (Holocaust Encyclopedia, 2017). The International Refugee Organization briefly took the UNRRA's place only to be replaced again by the UNCHR in 1950 .

The Hungarian Revolution of 1956 was the first substantial refugee resettlement project using modern refugee law. The majority of the 200 thousand Hungarian refugees fled to Austria. Austria quickly called upon the international European community to contribute equally to this refugee crisis:

Austria will therefore take into consideration the number of displaced persons to be received in proportion to the total population of Austria, and will compare that to the corresponding proportions in the other Member States in order to ensure that the burden is shared equally between all the EU Member States (Zieck, 2013: p. 62).

There was debate over how many states must "share the burden". The reset- 
tlement of these Hungarian refugees was relatively swift and shared among many states. Currently, relocating refugees happens seldom and is typically viewed as not ideal; however in this case, western states had motive to take in refugees. This refugee population was mostly young and could fill a void in labor. Amidst the Cold War ideology, the US and other democratic powers offered freedom to these freedom-fighters; these refugees had valuable inside information on the Soviet regime; and the conflict was short-lived with a clear ending (Zieck, 2013). Signing up to support refugees for a short-lived conflict is much more attractive than signing up for a decade-long conflict.

In 1975, the Vietnam War ended, which commenced a massive departure of Vietnamese refugees, primarily by boat. The lines of who was a refugee and who was an economic migrant became blurry as this exodus continued until 1988. More than 1 million Vietnamese left to start a new life outside their borders (Tran, 2015). The Comprehensive Action Plan was a coordinated resettlement strategy between Vietnam and western powers, which limited the number of people who qualified as refugees. After a decade of funding resettlement programs, host countries had "compassion fatigue" and were looking for exceptions to these rules so they could be excused from their responsibilities. The "boat people" are not the first example of states using exceptions to the rules, but this crisis illustrates when arguments against complying with international refugee agreements become mainstream.

Yet even "short" conflicts can be considered unattractive refugee obligations. After an embarrassing, failed-attempt of humanitarian peacekeeping in Somalia, Bill Clinton could not muster the congressional support to aid Rwanda before it was too late. Rwanda was not considered a geostrategic ally, and it does not have resources the US was hoping to exploit. Not reacting fast enough to prevent a genocide was equally embarrassing as Somali pirates were hijacking US aid. Some consider this lack of effort as racism, while others interpret this as merely political. Table 1 charts generalized refugee recovery trends throughout three historical phases.

\section{Current Refugee Policy Patterns}

\subsection{International Distribution of Resources}

Despite a country's good intentions of actually implementing policies to help

Table 1. This table summarizes and simplifies the three main attitudes toward refugee assistance in three time periods post World War II.

\begin{tabular}{|c|c|}
\hline Time Period & Refugee Recovery Trends \\
\hline $\begin{array}{l}\text { 1945-1960s Post-WWII } \\
\text { (Eurocentric Approach) }\end{array}$ & collective, comprehensive, international responsibility \\
\hline $\begin{array}{l}\text { 1960-1990s Cold War (East Asia), } \\
\text { Independence Wave(Africa) }\end{array}$ & $\begin{array}{l}\text { loop holes distinguishing refugees from economic } \\
\text { migrants emerge }\end{array}$ \\
\hline 1990s-Present Consistent Conflict & $\begin{array}{l}\text { overwhelmed by need and lacking collective international } \\
\text { responsibility }\end{array}$ \\
\hline
\end{tabular}


refugees, fiscal international support and internal autonomy greatly influence what can actually be done. The following pie charts in Figure 1 indicate the distribution of UN funding to the top six host countries. In 2015, the UNHCR needed roughly $\$ 7$ billion US dollars to fully satisfy the needs of displaced people and asylum seekers, but they only received $\$ 3,707,000$ (UNHCR, 2017). The UNHCR is a pooled, international effort. When specific conflicts lack political priority and a country is poor, caring for vulnerable people becomes an impossible task. Each host country has distinct resources and situations. Therefore, it is important to look at each of these countries individually. The following is a matrix of the top refugee hosting countries' profiles.

Ethiopia, Lebanon, Pakistan, Iran, Jordan, and Turkey all have varying: refugee planning strategies, histories between natives and refugees, ratios between native and refugees by population, GDPs, governmental autonomy, supporting organizations, and levels of overall success. Table 2 displays these disparities; each country's situation is discussed and evaluated going forward. Readers must remember that it is impossible to overtly compare these "successes" because each country possesses unique advantages and disadvantages which cannot be controlled for. This analysis discusses these scenarios to materialize patterns and tendencies of which planners should take note.

\subsection{Ethiopia}

Define abbreviations and acronyms the first time they are used in the text, even State newspapers claim the Federal Democratic Republic of Ethiopia is taking exceptional care of their 736 thousand refugees; however, this is simply not accurate. The unstable government of the country merely does not possess the capability to effectively protect its citizens, let alone thousands of refugees. The longstanding drought has devastated its agriculture-based economy, and political unrest compounds Ethiopia's refugee crisis. Despite Ethiopia having the lowest

UNHCR Total Budget Distribution

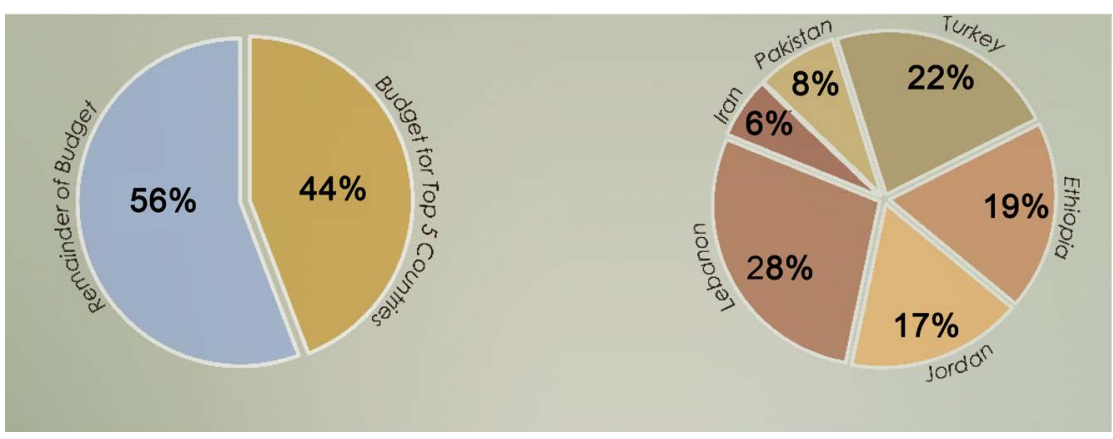

Figure 1. Pie charts depicting the UNHCR's budget distribution; this illustrates how some countries receive more resources than others. The data is from the UNHCR Financial Report. Questions on the quantity and sources of funding are important questions but further discussion on finances is outside the scope of this paper (UNHCR, 2017). 
Table 2. This table summarizes the top six host countries' refugee strategies as of spring 2017. The list of funding sources is not exhausting, but rather highlighting a few key players (United Nations Refugee Data, 2015).

\begin{tabular}{|c|c|c|c|c|c|c|c|}
\hline Country & $\begin{array}{c}\text { Number } \\
\text { of } \\
\text { Refugees }\end{array}$ & $\begin{array}{l}\text { Ratio of } \\
\text { Refugees } \\
\text { to Citizens } \\
\text { (per } 1000 \\
\text { Citizens) }\end{array}$ & $\begin{array}{c}\text { Refugee } \\
\text { per } \\
\text { GDP }\end{array}$ & $\begin{array}{c}\text { Host } \\
\text { Government } \\
\text { Status }\end{array}$ & Funding Sources & $\begin{array}{l}\text { Host Government's Relationship to } \\
\text { Refugees }\end{array}$ & $\begin{array}{l}\text { Integrated Resettlement or Temporary } \\
\text { Camps }\end{array}$ \\
\hline Ethiopia & 736,000 & 7.24 & 469.41 & Unstable & $\begin{array}{l}\text { UNHCR, International } \\
\text { Refugee Council, Save } \\
\text { the Children, Jesuit } \\
\text { Refugee Service, } \\
\text { Refuge Point, } \\
\text { Norweigan Refugee } \\
\text { Council, International } \\
\text { Organization for } \\
\text { Migration, World } \\
\text { Food Program }\end{array}$ & $\begin{array}{l}\text { Government has no internal capacity to } \\
\text { support refugees, nor is it interested in } \\
\text { doing so. A severe drought has devastated } \\
\text { Ethiopia's food security and economy. } \\
\text { Citizens, themselves appear to be } \\
\text { pseudo-environmental refugees A long, } \\
\text { complicated history of clashes between } \\
\text { ethnic groups fuels tensions between locals } \\
\text { and refugees. Many rebels are armed } \\
\text { because of a lack of security and spill over } \\
\text { conflict. }\end{array}$ & $\begin{array}{l}\text { Temporary Camp based, Eritreans with } \\
\text { family in Ethiopia can apply to leave the } \\
\text { camps and integrate in Addis Ababa, but } \\
\text { all refugees cannot work. Food assistance } \\
\text { is available but not food voucher e-cards. }\end{array}$ \\
\hline Lebanon & $\begin{array}{l}1.1 \\
\text { million }\end{array}$ & 208.91 & 80.83 & $\begin{array}{l}\text { Somewhat } \\
\text { Unstable }\end{array}$ & $\begin{array}{l}\text { UNHCR, Oxfam } \\
\text { America, Doctors } \\
\text { W/out Borders, World } \\
\text { Food Program, } \\
\text { Norweigan Refugee } \\
\text { Council, Inernational } \\
\text { Organization of } \\
\text { Migration }\end{array}$ & $\begin{array}{l}\text { The government is so overwhelmed by the } \\
\text { ratio of refugees to citizens; it has no } \\
\text { capacity to serve this population. Minimal } \\
\text { governmental recognition of refugees. } 70 \% \\
\text { of refugees are unregistered there because } \\
\text { the government makes the process } \\
\text { difficult. }\end{array}$ & $\begin{array}{l}\text { No temporary camps or subsidized } \\
\text { housing. Refugees mostly live in abandon } \\
\text { buildings/informal settlements. They } \\
\text { cannot (legally) work, most kids not in } \\
\text { school, they often sell candy in the streets. } \\
\text { Food voucher card system available. Cash } \\
\text { voucher e-cards available. }\end{array}$ \\
\hline Pakistan & $\begin{array}{l}1.6 \\
\text { million }\end{array}$ & 8.33 & 322.47 & $\begin{array}{l}\text { Relatively } \\
\text { Stable }\end{array}$ & $\begin{array}{l}\text { OPEC "Fund”, } \\
\text { UNHCR, Norweigan } \\
\text { Refugee Council, } \\
\text { International Refugee } \\
\text { Council, International } \\
\text { Organization for } \\
\text { Migration }\end{array}$ & $\begin{array}{l}\text { After the } 2014 \text { school bombing, the } \\
\text { government sees refugees as a threat to } \\
\text { national security and has started to } \\
\text { mistreat Afghans. The Pakistani } \\
\text { government has threatened to repatriate } \\
\text { Afghani refugees and overall has not } \\
\text { welcomed these refugees. }\end{array}$ & $\begin{array}{l}\text { Full, embracing integration resettlement } \\
\text { into society with jobs and schools-until } \\
9 / 11 \text { and then the } 2015 \text { repatriation } \\
\text { proclamation. Roughly } 2 / 3 \text { of refugees live } \\
\text { in the city and } 1 / 3 \text { live in camps. Camps } \\
\text { are along the border of Afghanistan. The } \\
\text { general public Pakistani citizens have a } \\
\text { sympathetic view of the Afghani people. } \\
\text { Refugees mainly from the Pashtun tribe } \\
\text { which is culturally similar/integrates well } \\
\text { in Pakistan. }\end{array}$ \\
\hline Iran & 979,000 & 12.53 & 56.4 & Stable & $\begin{array}{l}\text { UNHCR, Relief } \\
\text { International, } \\
\text { Norweigan Refugee } \\
\text { Council, World FOod } \\
\text { Program }\end{array}$ & $\begin{array}{l}\text { Refugees are mostly Hazara and Tajiks in } \\
\text { Iran. The government has encouraged } \\
\text { voluntary repatriation to Afghanistan. } \\
\text { Government makes it difficult to obtain } \\
\text { refugee asylum status if one is born in Iran } \\
\text { from Afghan-refugee parents. Iran has a } \\
\text { similar repatriation policy as Pakistan in } \\
\text { recent years. }\end{array}$ & $\begin{array}{l}\text { Most refugees live in cities, some live in } \\
\text { camps, and only } 3 \% \text { in rural settings. } \\
\text { Afghans in Iran experience strong } \\
\text { discrimination, difficult to find work. } \\
\text { Refugees receive food rations but not food } \\
\text { voucher e-cards. }\end{array}$ \\
\hline Jordan & 664,000 & 89.55 & 61.64 & Stable & $\begin{array}{l}\text { UNHCR, CARE-runs } \\
\text { both camps, Oxfam } \\
\text { America, Doctors } \\
\text { W/out Borders, } \\
\text { Norwegian Refugee } \\
\text { Council, International } \\
\text { Organization for } \\
\text { Migration, World } \\
\text { Food Program }\end{array}$ & $\begin{array}{l}\text { At first the government was amiable } \\
\text { towards refugees, being used to routine } \\
\text { refugee influxes. Now fatigued, taking a } \\
\text { toll on its own citizens/economy. However } \\
\text { the newspapers boast in the Queen's call to } \\
\text { care for these refugees. }\end{array}$ & $\begin{array}{l}80 \% \text { of refugees live outside of camps, } \\
\text { integrated into the cities. Refugees in } \\
\text { camps have their own economies and are } \\
\text { evolving into cities. Camp borders are } \\
\text { relatively perilous and goods come in and } \\
\text { out of camps. Refugees have overwhelmed } \\
\text { the housing market, increasing rent by } \\
75 \% \text {. Thus now, incoming refugees stay in } \\
\text { the camps and it is difficult to get out. } \\
\text { Food rations are distributed p in camps, } \\
\text { but outside of camps only meals are } \\
\text { provided at schools. }\end{array}$ \\
\hline
\end{tabular}


refugees-per-1,000-citizen ratio of this study group 7.24, it has the most refugees-per-dollar of GPD 469.41 (United Nations Refugee Data, 2015). This is refugees to GDP per capita. The overwhelming majority of refugees in Ethiopia are South Sudanese, Somali, and Eritrean (UNHCR, 2016). Unfortunately, these incoming populations have an extensive and complicated history with Ethiopians. Ethnic clashes and lack of resources have pushed Ethiopia to take a mostly non-integration refugee policy. Apart from Eritreans, by default all other refugees must remain in camps, have very limited mobility, cannot work, and rely on food distributions. Near the Gambella region, occasionally refugees will work on reforestation, beehive sites, or farms. These are initiatives by the UN. Tensions are growing between the seemingly helpless and frustrated refugees and the UNHCR, ARRA, and local populations (Jeffery, 2015). Most of the refugee camps are outside of main cities, making the ratio between native populations and displaced populations disproportionately high. This counters the 1951 Convention, which guarantees freedom of movement and employment. Ethiopia's largest refugee camp, in Gambella, has 270,000 refugees and 300,000 native residents (Boradhurst, 2016). Refugees escaping violence in South Sudan could easily bring guns into the refugee camps in Gambella (Soloman, 2016). This southeastern region is further complicated by territorial and ethnic clashes, which date back for centuries. The Nuer peoples, from South Sudan, culturally conflict with the Anuyak peoples of Ethiopia.

Contrasting to most refugees' experience in Ethiopia, if Eritreans have family sponsors, they are permitted to live integrated lives in the capital city, Addis Ababa. However, even Eritreans cannot work in Ethiopia; thus, most Eritreans attempt to leave Ethiopia for Israel, Egypt, or Europe.

The status of refugees in Ethiopia is certainly not good, and most likely not changing anytime soon. Out of fear and desperation, refugees are mostly isolated from society with no mobility. This system of continuously handing out supplies at camps, and not enabling this new population, causes refugees in Ethiopia to be dependent on the generosity of others (nonprofits) to live. This model is unsustainable, but understandable considering where Ethiopia is at economically and politically.

\subsection{Lebanon}

The Lebanese Republic has 1.1 million refugees living among its small population of roughly 4.5 million citizens, resulting in a staggering 208.91 refugees-per1000-citizens (United Nations Refugee Data, 2015). Although the GDP ratio is better than most in this study 80.83 , Lebanon is beyond overwhelmed with the incoming Syrian population. The government has made the process of registering as a refugee extensive and difficult to deter the number of vulnerable people they are responsible for supporting. The burden of refugee planning is so intimidating; the government attempts to ignore it as much as possible. According to the UNHCR, Lebanon has received only $2 \%$ of the funding it requested to as- 
sist it (Inter-agency Information Portal, 2017).

Lebanon has a prolonged history of housing refugees (Palestinians) who often live in camps for generations. For this reason, the government decided not to construct camps for the incoming Syrian refugees (Rosenberg, 2013). Refugees live primarily in abandoned buildings within their cities, and are not allowed to work. Most children are not enrolled in school, and, instead, work alongside their parents doing odd jobs. One positive attribute to refugee planning in Lebanon is the UN World Food Program's cash stipend card. Depending on need, families receive appropriated amounts of money per month on these cards, which contribute to food, rent, and other necessities (Rosenberg, 2013). These cards give refugees the autonomy to personalize decisions for their family, and support the local economy, instead of requiring refugees to wait in lines for daily food rations in camps. Refugees are mostly clustered in cities beside the Syrian border, far away from Beirut. Proportionally, Lebanon simply has too many refugees. Its minimalistic, integrative system is probably the best policy the government could muster from the extremely limited support it accrues. However, when a country's population increases by nearly $25 \%$, the need for new infrastructure, housing and schools, everything changes. Much more outside assistance is necessary in Lebanon for this to end well for refugees and Lebanese citizens.

\subsection{Pakistan}

The Islamic Republic of Pakistan hosts 1.6 million refugees. Comparing the number of refugees to Pakistan's bountiful population, its refugees-per-1000-citizens is only 8.33. However, the GPD to refugee ratio is 322.47 , which limits Pakistan's ability to serve and protect asylum seekers and its own citizens.

In the 1970s, Pakistan openly welcomed Afghans escaping the Soviet invasion. These refugees were mostly from the Pashtun tribe, which fit into Pakistani culture nicely (BBC, 2016). The Pakistani government saw welcoming this population as a strategy to combat the Soviets by recruiting men in Islamist fronts. These Afghan refugees could work and integrate into society, and the government pressured refugees to identify as Muslims before Afghans to integrate them more (BBC, 2016). There are camps along the Afghan border, but most refugees just began new lives in Pakistan with an amiable relationship with locals, until September 11, 2001.

Even before the terrorist attacks in the US, in November 2000, the Pakistani government commenced efforts to close off the Afghan border. Subsequently, the government began monetarily incentivizing refugees to repatriate voluntarily to Afghanistan. Throughout the 2000s, offshoots of the anti-Pakistani Taliban sprouted up near campsites. In 2014, the Taliban's attack on the Public Army School soured the relations between the Pakistani government and the Afghan refugees (BBC, 2016). Police harassment followed along with diminishing support. By the end of 2015, 58,211 Afghans in Pakistan repatriated back to Afghanistan (UNHCR, 2016). Tensions climaxed in December 2015 when the Pakista- 
ni government announced it would give refugees six months to repatriate back to Afghanistan. These policy-reactions would have been vastly different had this happened in the 1950s. How does the UNHCR not see this as a direct violation of the 1951 Convention's forced repatriation clause? The Pakistani government has recently bullied the Afghan refugees so much that many feel coerced to return to Afghanistan. A 2017 Human Rights Watch report claims that:

Afghan refugees told Human Rights Watch that a toxic combination of insecure legal status, the threat of deportation during winter, and police abuses-including crippling extortion, arbitrary detention, and nocturnal police raids-had left them with no choice but to leave Pakistan (Human

Rights Watch, 2017).

The refugee experience in Pakistan has been dynamic. Considering its autonomy, Pakistan was working well with refugees; however as national security was threatened, its displaced persons policy was turned upside down. Regarding pre-9/11 methods, Pakistan served as an example for impoverished states facing refugee problems. One must consider Pakistan's unique situations, which permitted successful refugee resettlement: common religion, often times common language, large host population, thus a lower refugee-citizen ratio, and, in the 1970s, the refugees were militarily strategic. With that said, perhaps this refugee story is difficult for struggling countries, like Ethiopia, to imitate. One must also note that Pakistan failed to protect refugees in times of war as promised in the Fourth Geneva Conventions (Geneva Conventions, 1950). The international community did not effectively enforce these binding standards; this sets new precedents for how other states mitigate refugee trials.

\subsection{Iran}

The Islamic Republic of Iran followed a similar refugee policy-path to Pakistan. Iran hosts 979 thousand refugees, with a 12.53 refugees-per-1000-citizens ratio. This means Iran has the fourth largest refugee population in the world. Unlike Pakistan, Iran is more prosperous, with 56.4 refugees per dollar of GDP (United Nations Refugee Data, 2015).

Iran's refugees, mainly from Afghanistan and some from Iraq, live mostly in the cities among Iranians and can work as long as they have a registered refugee identification card called an Amayesh card. This registration process is purposely long and strenuous. Inter-generational refugee families further complicate this documentation process. The government often does not accept people born from two Afghans in Iran to register as a refugee or as a citizen. The government estimates that another 1.5 to 2 million undocumented Afghans reside in Iran (UNHCR, 2016). Documented persons have relatively respectable access to health, education, and other services. However, after hosting refugees for years, Iran has compassion fatigue. Alike Pakistan, in 2000 Iran started closing its Afghan border, thus blocking further refugees from entering. An estimated 10 thousand refu- 
gees live in the Mile 46 and Mekaki camps in Afghanistan near the Iranian border (Human Rights Watch, 2002). Iran has implemented repatriation efforts similar to Pakistan, but with far fewer refugees deciding to return to Afghanistan. Perhaps this is because, although there is discrimination in Iran, it provides more opportunity than Afghanistan. Here, refugees prioritize resources over social harmony, which is not the case in Turkey and other places.

Refugees are not a new concept for Iran. Integrating them in cities is not the issue; instead, refugees must hurdle over bureaucratic loopholes that prevent people from registering as refugees. For generational cases like Iran, one must ask for exactly how long should a person be a registered refugee? Should refugee children not born in the "home country" be counted in social programs? Iran has yet to answer these important questions.

\subsection{Jordan}

The Hashemite Kingdom of Jordan has 664 thousand refugees, making its refugees-per-1000-citizens ratio the second highest of this study at 89.55 . Fortunately, Jordan has the second-best refugee-GDP ratio (United Nations Refugee Data, 2015). Jordan's approach to its current refugees is evolving as its resources and generosity grow weary. Initially, all refugees could settle into their cities and start their new lives alongside Jordanians. Influxes of refugees are routine to Jordan; Syrian refugees settling in Jordan was not shocking or unwelcomed, at first. After several years, the housing market, job demand, and need for schools exploded. In 2012, the government started to limit the number of refugees by placing them in camps. Currently, refugees need a sponsor to live in cities (Fröhlich et al., 2015). Despite these restrictions, $80 \%$ of the refugees live outside the camps (Ingrasci et al., 2015). However, when living outside, it is difficult to find consistent work, and food is only distributed at schools for children. Recently, refugees have begun to encounter "random-ID checks" to confirm that they are allowed to be outside of camps. In the camps, shelter and food are accounted for.

The camps, particularly the Za'atari camp, have morphed into semi-functioning cities. Za'atari is the second-largest refugee camp in the world, and, at one point, was Jordan's "fourth largest city" (Ingrasci et al., 2015). This camp has an informal economy from smuggled in goods. Za'atari's economy has brought on a sense of belonging and purpose to its residents internally, and it contributes to the greater Jordanian economy as well. UN workers know these informal exchanges are occurring, but they mostly permit it, seeing it as an opportunity to jump-start a shrinking city (Kimmelman, 2014).

Despite the increased demands for housing and jobs, the relationship of Jordanians with refugees is positive overall. Refugees are a normalized occurrence; Syrians and Jordanians both speak Arabic and are mostly Sunni Muslim. The royal monarchy continues to appear devoted to aiding its Muslim brothers and sisters. The welcoming, integrated approach, along with being used to refugees, having a decent GDP, and sharing the same culture, all contribute to a relatively 
"successful" refugee policy in Jordan.

\subsection{Turkey}

The Republic of Turkey currently hosts the most refugees in the world, with 2.5 million displaced persons. Despite having the most vulnerable incoming people, Turkey has a large national population of about 75 million, and thus a much smaller refugee-per-1000-citizen ratio of 23.72 (United Nations Refugee Data, 2015).

Eighty percent of refugees live outside of camps due to overcrowding and the inability to work if one lives within a camp. Living integrated lives, refugees receive cash vouchers each month from CARE and the World Food Programme. Like Lebanon, refugees in Turkey can make daily choices for their family and contribute to local economies (Sreenivasan, 2017). On paper, Syrians have access to Turkish healthcare, schools, and work permits. However, these amenities and opportunities are mostly available in the large cities where rent is really expensive. Economically and culturally, the Syrian refugees fit into the southeastern, Kurdish region of Turkey. Unfortunately, these towns are small and cannot hold all of these people. The mayor of a town called Kilis explained that, "Before the crisis, street cleaners collected 30 tons of rubbish a day; now it is 160 . Water consumption has tripled; the amount of green space per person has shrunk from five square meters to just over one" (Richard, 2016).

Overall, Turkey's refugee system is relatively good, but would be more effective if the "provided services" like health and education, were in the places where refugees lived. These refugees cannot use these resources as long as they do not have access to them. With more attention and investment, the cities of Turkey's southeastern region could support these needs and stimulate long lasting growth. Unfortunately, Turkey's government has other priorities and internal dilemmas.

\section{Application to Future Policy}

What can planners and policy-makers learn from this research? Firstly, this paper notes that there is no completely transferable "formula" for refugee crisis policy creation. Every country has a different history, relationship with said incoming population, autonomy, budget, amount of international support, set of priorities, and population sizes. A number of these attributes simply cannot change due to a proposed plan when confronted by hundreds of years of history between peoples, religious differences, duration of conflict time, etcetera.

However, by comparing these six approaches, one can see a few overarching positive, transferable policies, which could be similarly used in different contexts. For instance, refugees do arguably better when they are structurally, economically, and socially integrated with the local population. Cards with monthly stipends allow families to participate in the local economy while making decisions on how to spend their money and feed their children. Getting refugees out of prison-like camps and into local shops, schools, and streets gives them dignity 
and a "more normal" life. Ethiopia's policy of keeping refugees in camps without working can bring out the worst in people. Refugees spend their days sitting around in pent-up anger and waiting in line for food. This is a life of imprisonment and helplessness. In contrast, the Jordanian camps function as a microcosm of a city; they have markets, schools, and relative peace. In Turkey, where refugees have the choice to live in camps or in the cities, most choose the cities. Although these cities are overwhelmed by refugees so that it is difficult to have enough services, these refugees can legally work, choose where to live, decide what to eat, and feel like people opposed to cattle. Despite possible discrimination from natives, refugees living in and contributing to cities have a more fulfilled life than those living in camps without choices.

For these integrated policies to materialize, a host country must accept a refugee population as new permanent residents, and not as a temporary favor. Most of the time, countries absolutely do not want to adopt a refugee population as their own residents. This hesitation in absorbing refugees has dwindled as the proportional assumption, in which the international community collectively adopts vulnerable peoples in relation to their capability, is no longer a trend. The attitude toward the Hungarian refugees in 1956 entirely diverges from the attitudes and assumptions of today. The 1967 Protocol Relating to the Status of Refugees endures on paper, yet is nullified in practice. Perhaps if the international community continued to take proportional responsibility for refugee resettlement, then countries would not resist these incoming populations.

Considering that presently, shifting refugee populations are not proportional to population, space, or budget, host countries must withstand quick demographic changes. In a practical sense, it is cumbersome to adjust labor and housing markets, school distributions, sewer lines, bus routes, roads, political precincts, and more. Perhaps a greater stymie to admitting a refugee population is cultural clashes. Inviting a new people into an area means potentially losing cultural identity. New languages, social practices, food demands, and political priorities follow immigrant populations. When the refugee and host country's cultures dramatically differ, locals feel culturally threatened. This threat is compounded if there is an actual history of violence between said groups. For instance, the Nuer and Anuyak peoples in Ethiopia have experienced intermittent conflict for centuries; one can see why Ethiopia chooses to keep their refugees separated from society, in camps. Depending on the situation, the refugees themselves may also not want to integrate with the locals. Many Syrian refugees emphasize their plan is to move back to Syria. Syrians in Turkey prefer living in the southern, Kurdish region for cultural reasons, even though western Turkey has more employment and resources. They see the discrimination in Europe, and they do not want to move there, fearing their children would lose their Muslim identity.

This phenomenon is not unique to these host countries, but is found everywhere. Throughout US history, there has always been an unwelcomed immigrant group; currently it is Mexicans and Muslims. If there were currently English-speaking Christian, British, or Canadian refugees, instead of Muslims from Syria, would there 
be such hostility in welcoming them?

It is no elementary task to change the hearts and minds of individual prejudice. A possible solution for refugee situations such as this could be setting up camps as a designated place for refugees, but integrating their markets. The Za'atari camp in Jordan serves as a model, although these populations get along culturally. Za'atari has informal work within the camp and contributes to the greater economy outside. This camp is so established that one can find two restaurants with ratings and reviews on Google Maps within it. These compounds could provide employment opportunities within the camp and trade these goods outside the site. Camps could become temporary, independent, and quasi-selfsupporting cities. This would give refugees a sense of purpose.

The author of this paper invites further research on these complicated and nuanced refugee models. Certainly, this analysis does not encompass all refugee experiences and planning; however, this offers insight to how the international community could improve conditions for millions of vulnerable people by recognizing what conditions tend to produce effective and ineffective policies.

\section{Acknowledgements}

The author extends her gratitude to Dr. David Edelman for his guidance and mentorship.

\section{Notes}

1) The definition of refugee excludes the 65.3 million forcibly displaced persons and the estimated 10 million stateless persons.

2) Numbers and statistics may have changed since the research conducted and paper publication date.

\section{References}

BBC (2016). The Reverse Exodus of Pakistan's Afghan Refugees.

http://www.bbc.com/news/world-asia-37163857

Boradhurst, C. (2016). More Violence Forecast in Ethiopia's Gambella as Death Toll Rises. http://en.rfi.fr/africa/20160425-violence-forecast-gambella-ethiopia-death-toll-rises

Eichengreen, B., \& Ritschl, A. (2008). Understanding West German Economic Growth in the 1950s, Working Paper. http://www.lse.ac.uk/economicHistory/pdf/WP113.pdf

Fröhlich, C., \& Stevens, M. R. (2015). Trapped in Refuge: The Syrian Crisis in Jordan Worsens, Middle East Research and Information Project. http://reliefweb.int/report/jordan/trapped-refuge-syrian-crisis-jordan-worsens

Geneva Convention (1950). Article 44, Geneva Convention Relative to the Protection of Civilian Persons in Time of War, 75 U.N.T.S. 287, Entered into Force Oct. 21, 1950. http://hrlibrary.umn.edu/instree/y4gcpcp.htm

Holocaust Encyclopedia (2017). United Nations Relief and Rehabilitation Administration. https://www.ushmm.org/wlc/en/article.php?ModuleId=10005685

Human Rights Watch (2002). Closed Door Policy: Afghan Refugees in Pakistan and Iran 2002. http://www.refworld.org/docid/3c7ce78a4.html 
Human Rights Watch (2017). Pakistan: Mass Forced Returns of Afghan Refugees: UN Refugee Agency Complicit in Government Coercion.

https://www.hrw.org/news/2017/02/13/pakistan-mass-forced-returns-afghan-refugees

Ingrasci, Z., \& Temple, C. (2015). Salam Neighbor; Living on One. 1001 Media, Documentary on Netflix.

Inter-Agency Information Portal (2017). Regional Refugee Response. http://data.unhcr.org/syrianrefugees/country.php?id=122

International Justice Center (2017). Asylum and the Rights of Refugees. http://www.ijrcenter.org/refugee-law/

Jeffery, J. (2015). Stuck in Limbo in Ethiopia, Africa's Biggest Refugee Camp. Deutsche Wells.

http://www.dw.com/en/stuck-in-limbo-in-ethiopia-africas-biggest-refugee-camp/a-188 $\underline{48086}$

Kimmelman, M. (2014). Refugee Camp in Jordan Emerges as a Do-It-Yourself City. New York Times.

https://www.nytimes.com/2014/07/05/world/middleeast/zaatari-refugee-camp-in-jorda $\underline{\text { n-evolves-as-a-do-it-yourself-city.html?_r }=0}$

Richard, S. (2016). Turkish Town at Centre of Syrian Refugee Crisis Says: We're Full. The Telegraph.

http://www.telegraph.co.uk/news/2016/04/19/turkish-town-at-centre-of-syrian-refugee -crisis-says-were-full/

Rosenberg, T. (2013). For Refugees in Lebanon, Cash Instead of Camps. New York Times.

https://www.nytimes.com/2016/09/13/opinion/for-refugees-in-lebanon-cash-instead-of -camps.html?_r=0

Soloman, S. (2016). Tracing the Source of Ethnic Clashes in Ethiopia's Gambella Region. VOA.

http://www.voanews.com/a/tracing-source-ethnic-clashes-ethiopia-gambella-region/31 97700.html

Sreenivasan, H. (2017). Inside the Harsh Living Conditions for Syrian Refugees in Turkey, PBS.

http://www.pbs.org/newshour/bb/inside-the-harsh-living-conditions-for-syrian-refuge es-in-turkey/

Tran, O. (2015). From "Boat People" to "Irregular Maritime Migrants": A Re-Conceptualization of Seaborne Refugees after 40 Years. Espmi Network.

https://refugeereview2.wordpress.com/2015/05/24/from-boat-people-to-irregular-marit ime-migrants-a-re-conceptualization-of-seaborne-refugees-after-40-years/\#_ftn3

UNHCR (2015). What Is a Refugee.

http://www.unrefugees.org/what-is-a-refugee/

UNHCR (2016). Ethiopia Fact Sheet November 2016.

https://data2.unhcr.org/en/documents/download/53122

UNHCR (2016). Global Focus Worldwide Operations: Pakistan.

http://reporting.unhcr.org/node/2546

UNHCR (2016). Iran Fact Sheet May 2016.

http://reporting.unhcr.org/sites/default/files/UNHCR\%20Iran\%20Factsheet\%20-\%20M AY16.pdf

UNHCR (2017). Figures at a Glance.

http://www.unhcr.org/en-us/figures-at-a-glance.html 
UNHCR (2017). Financial Report.

http://reporting.unhcr.org/financial\#_ga=1.268058382.1417284858.1485191986

United Nations (1948). Article 14, Universal Declaration of Human Rights. General Assembly, res. 217A (III), U.N. Doc A/810 at 71.

http://www.un.org/en/udhrbook/pdf/udhr_booklet_en_web.pdf

United Nations (1951). Convention and Protocol Relating to the Status of Refugee of 1951. https://drive.google.com/drive/folders/0B9hdgyqxIyKQa0hrRiljRGNPR3c

United Nations (1967). Protocol Relating to the Status of Refugees of 1967. https://drive.google.com/drive/folders/0B9hdgyqxIyKQa0hrRiljRGNPR3c

United Nations Refugee Data (2015). Table 14. Indicators of Host Country Capacity and Contributions, Mid-2015.

https://docs.google.com/spreadsheets/d/106CvO9NRykvvevasOshHxX_vp65UkRpL44 aL5e_PAPo/edit\#gid=868430349

Zieck, M. (2013). The 1956 Hungarian Refugee Emergency, an Early and Instructive Case of Resettlement. Amsterdam Law Review, 5, 45-63.

http://amsterdamlawforum.org/article/viewFile/314/487 